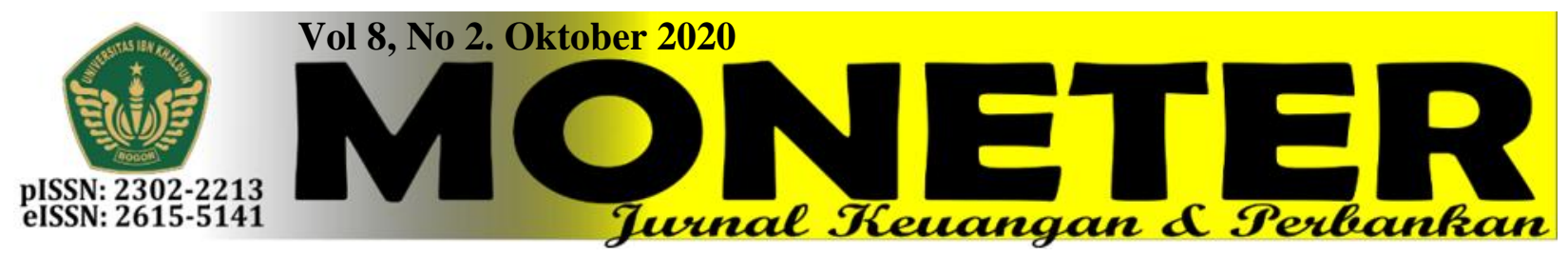

\title{
ANALISIS KINERJA KEUANGAN DALAM KEPUTUSAN STOCK SPLIT
}

\author{
Oleh: \\ Denia Maulani ${ }^{1)}$ \\ FEB Universitas Ibn Khaldun Bogor \\ denia@uika-bogor.ac.id
}

\begin{abstract}
ABSTTRACT
Activities in the capital market, one of which is the stock split decision, has a role in stock trading on the Indonesia Stock Exchange (IDX) and the mechanism for selling securities traded and issued by each company. The purpose of this study is to determine the financial performance before and after the stock split. The company's financial performance fundamentals use several financial ratios that are used, namely the current ratio, the leverage ratio (leverage ratio) and ROA (return on assets). The companies selected as samples are companies that are members of the LQ 45 on the IDX from 2006 to the first semester of 2012 which carry out a stock split policy. The first test uses the Klomogrov-Smirnov test to test data normality. The results of this test indicate the value of the research data is normally distributed. In addition, in this study, paired different samples were used to test the hypothesis at alpha $5 \%$.
\end{abstract}

Keywords: Financial performance, Current ratio, Leverage ratio, ROA, stock split.

\section{ABSTRAK}

Kegiatan di pasar modal, salah satunya yaitu keputusan stock split memiliki peran dalam perdagangan saham di Bursa Efek Indonesia (BEI) dan mekanisme penjualan surat berharga yang diperdagangkan dan diterbitkan oleh masing-masing perusahaan. Tujuan dari kajian ini yaitu untuk mengetahui kinerja keuangan sebelum dan setelah stock split. Fundamental kinerja keuangan perusahaan menggunakan beberapa rasio keuangan yang digunakan yaitu current ratio, rasio leverage (leverage ratio) dan ROA (return on asset). Perusahaan yang dipilih sebagai sampel adalah perusahaan yang tergabung dalam LQ45 di BEI tahun 2006 sampai dengan semester pertama tahun 2012 yang melakukan kebijakan stock split Pengujian pertama menggunakan uji Klomogrov-Smirnov untuk menguji normalitas data. Hasil pengujian ini menunjukkan nilai data penelitian berdistribusi normal. Selain itu, dalam penelitian ini menggunakan uji beda sampel berpasangan untuk pengujian hipotesis pada alpha $5 \%$.

Kata Kunci: Kinerja keuangan, Current ratio, Leverage ratio, ROA, Stock split. 


\section{PENDAHULUAN}

Pasar modal sebagai suatu sistem yang terorganisasi di dalam mekanisme perdagangan efek (Tandelilin, 2010). Selain itu juga pasar modal merupakan bagian dari lembaga keuangan (financial institution) yang memiliki peranan penting dengan memberikan berbagai informasi yang diperlukan oleh calon investor untuk memenuhi mekanisme perdagangan yang ada baik yang tersedia di publik seperti halnya pada keputusan stock split atau pemecahan saham (Kasmir, 2014).

Pemilihan rasio keuangan yang tepat dalam penelitian ini diantaranya yaitu: pertama, rasio likuiditas dengan menggunakan current ratio. Kedua, rasio solvabilitas dengan menggunakan leverage ratio. Ketiga, rasio profitabilitas dengan menggunakan ROA (return on asset) dengan laporan keuangan selama periode mulai dari tahun 2006 sampai dengan semester pertama tahun 2012(Gitman \& Zutter, 2015). Tujuan dari dilakukannya penelitian ini adalah untuk menilai kinerja keuangan dari sebelum dan sesudah stock split.

\section{METODOLOGI}

Data yang digunakan dalam penelitian ini adalah data sekunder yang berasal dari berbagai sumber, antara lain JSX Annual, Indonesian Capital Market Directory (ICMD) dan Indonesian Capital Market Electronic Library tahun 2006 sampai dengan semester pertama tahun 2012, laporan keuangan tahunan ICMD dan IDX LQ 45 magazine sampai dengan edisi february 2012. Alasan penggunaan data sekunder dengan pertimbangan bahwa data ini mudah diperoleh, lebih murah, mempunyai rentang waktu dan ruangnya luas. Selain itu penggunaan data sekunder dalam penelitian sudah lazim digunakan dan penggunaan laporan keuangan untuk perusahaan go public (Maulani et al., 2019).

Analisa data yang menggunakan variabel-variabel independen dengan ukuran rasio dengan statistik parametris dalam melakukan uji parameter populasi, melalui sampel yang digunakan (Sugiono, 2014). Data pada setiap variabel terlebih dahulu diuji dengan menggunakan kolmogorov-smirnov test (Basuki \& Nazaruddin, 2016).

\section{HASIL PEMBAHASAN}


Tabel 1.1

\section{Pengujian Hipotesis Current ratio}

\begin{tabular}{lr}
\hline \multicolumn{1}{c}{ KETERANGAN } & \multicolumn{2}{c}{ HASIL } \\
\hline Mean Sebelum Stock Split & 2,2211 \\
\hline Mean Sesudah Stock Split & 2,6111 \\
\hline t hitung & $-1,158$ \\
\hline Signifikansi & 0,280 \\
\hline$N$ & 9
\end{tabular}

Sumber: Output SPSS 22

Tabel 1.1 menunjukkan mean current ratio sebesar 2,2211 lebih kecil daripada sesudah stock split yaitu sebesar 2,6111. Hal ini berarti bahwa current ratio antara sebelum dan setelah stock split cenderung positif. Kemudian diuji untuk mengetahui tingkat signifikansinya. Diketahui bahwa $\mathrm{t}$ hitung dari output sebesar -1,158, tingkat signifikansi $\alpha(0,05)$ dengan tingkat kepercayaan 95\%, nilai tabel t sebesar 2,3060. Dari pengujian uji t maka selanjutnya dilakukan perbandingan diantara keduanya, bahwa $(-1,158) \leq(2,3060)$ maka $\mathrm{H}_{0}$ diterima.

\section{Tabel 2.1}

\section{Pengujian Hipotesis Leverage Ratio}

\begin{tabular}{lr}
\hline \multicolumn{1}{c}{ KETERANGAN } & \multicolumn{2}{c}{ HASIL } \\
\hline Mean Sebelum Stock Split & 0,4911 \\
\hline Mean Sesudah Stock Split & 0,4733 \\
\hline t hitung & 0,713 \\
\hline Signifikansi & 0,496 \\
\hline N & 9 \\
\hline
\end{tabular}

Sumber: Output SPSS 22

Tabel 2.1 menggambarkan rata-rata leverage ratio antara sebelum stock split sebesar 0,4911 lebih besar daripada sesudah stock split yaitu sebesar 0,4733. Hal ini berarti bahwa leverage ratio antara sebelum dan setelah stock split cenderung negatif. Kemudian diuji untuk mengetahui tingkat signifikansinya. Diketahui bahwa t hitung dari output sebesar 0,713 , tingkat signifikansi $\alpha(0,05)$ 
dengan tingkat kepercayaan 95\%, nilai t tabel 2,3060. Dari pengujian uji t maka selanjutnya dilakukan perbandingan diantara keduanya, $(0,713) \leq(2,3060)$ maka $\mathrm{H}_{0}$ diterima.

Tabel 3.1

Pengujian Hipotesis ROA (retun on assets)

\begin{tabular}{lr}
\multicolumn{1}{c}{ KETERANGAN } & \multicolumn{1}{l}{ HASIL } \\
\hline Mean Sebelum Stock Split & 17,0411 \\
\hline Mean Sesudah Stock Split & 11,7856 \\
\hline t hitung & 0,828 \\
\hline Signifikansi & 0,431 \\
\hline $\mathrm{N}$ & 9 \\
\hline
\end{tabular}

Sumber: Output SPSS

Tabel 3.1 menggambarkan rata-rata retun on assets antara sebelum stock split sebesar 17,0411 lebih besar daripada setelah stock split yaitu sebesar 11,7856. Hal ini berarti bahwa retun on assets antara sebelum dan sesudah stock split cenderung negatif. Kemudian diuji untuk mengetahui tingkat signifikansinya. Diketahui bahwa t hitung dari output sebesar 0,828, tingkat signifikansi $\alpha$ $(0,05)$ dengan tingkat kepercayaan 95\%, nilai t tabel sebesar 2,3060. Dari pengujian uji t maka selanjutnya dilakukan perbandingan diantara keduanya, $t$ hitung $(0,828) \leq t$ tabel $(2,3060)$ maka $\mathrm{H}_{0}$ diterima.

\section{KESIMPULAN}

Kesimpulan dari penelitian ini sebagai berikut:

1. Hipotesis satu menunjukan bahwa bahwa $(-1,158) \leq(2,3060)$ maka $\mathrm{H}_{0}$ diterima. Dari pengujian ini dengan menggunakan nilai probabilitas maka diperoleh bahwa nilai probabilitas $(0,280)>0,05$. Dapat disimpulkan, current ratio antara sebelum dan setelah stock split tidak terdapat perbedaan signifikan pada $\alpha 5 \%$.

2. Hipotesis kedua menunjukan bahwa $(0,713) \leq(2,3060)$ maka $\mathrm{H}_{0}$ diterima. Pengujian dengan menggunakan nilai probabilitas diperoleh bahwa nilai probabilitas $(0,496)>0,05$, kondisi 
tersebut menggambarkan leverage ratio antara sebelum dan setelah stock split tidak terdapat perbedaan signifikan pada $\alpha 5 \%$.

3. Hipotesis ketiga menunjukan bahwa $(0,828) \leq(2,3060)$ maka $\mathrm{H}_{0}$ diterima. Pengujian dengan menggunakan nilai probabilitas diperoleh bahwa nilai probabilitas $(0,431)>0,05$. Maka dapat disimpulkan retun on assets antara sebelum dan setelah stock split tidak terdapat perbedaan signifikan pada $\alpha 5 \%$.

\section{DAFTAR PUSTAKA}

Basuki, A. T., \& Nazaruddin, I. (2016). Analisis Statistik Dengan SPSS. Analisis Statistik Ekonomi Dan Bisnis Dengan SPSS.

Gitman, L. J., \& Zutter, C. J. (2015). Principles of Managerial Finance 14th Edition. In Pearson Education.

Indonesia Stock Exchange Research and Development Division. (2015). IDX Monthly Statistics. Development.

Kasmir. (2014). Bank dan Lembaga Kuangan Lainnya. In PT. Raja Grafindo Persada jakarta.

Maulani, D., Rinda, R. T. K., \& Rumiasih, N. A. (2019). Kinerja Keuangan Terhadap Return Saham. INOVATOR. https://doi.org/10.32832/inovator.v8i1.1839

Sugiono, P. D. (2014). Metode penelitian pendidikan pendekatan kuantitatif.pdf. In Metode Penelitian Pendidikan Pendekatan Kuantitatif, Kualitatif Dan R\&D.

Tandelilin, E. (2010). portofolio dan investasi. In Kanisius. 